\title{
Becoming a Visual Anthropologist
}

\author{
Howard Morphy
}

Histories are full of pitfalls, especially if written by those who have had a part in them.

\section{- David MacDougall ${ }^{1}$}

I have decided to use biography as the framework for this essay. Ethnographic film has been central to my engagement with anthropology since first coming from University College London to The Australian National University as a graduate student in 1973. My career as an anthropologist has been unusual in that I have always been in environments where ethnographic film was considered an integral part of at least some of my teachers' and colleagues' conception of anthropology.

I came to University College London as an undergraduate to study social anthropology. My aim was to learn as much as I could about the ways of life of people of the 'developing' world as preparation for a career helping alleviate hunger and disadvantage. While I like to think I have never lost the motivation to work with people for the betterment of the world, I developed a specialist interest in the anthropology of art and material culture as a result of the courses I studied and the charismatic teaching of a young lecturer, Peter Ucko. The first ethnographic films that I watched were part of the courses that he taught. The films were made under the auspices of the Institut für den Wissenschaftlichen at Göttingen in Germany. The emphasis of the institute was on scientific purity and the comparative method. ${ }^{2}$ The films selected focused on technical processes in the manufacture and use of material-culture objects. Science in this context often seemed too objectifying, looking at the technical processes of distant cultures as if they were disconnected from the overall life of the society. Nonetheless, while sitting in the darkened lecture theatre with the films in glistening black and white, I found the magic of film was not entirely absent.

\footnotetext{
1 MacDougall, D. 2001-02, 'Colin Young, ethnographic film and the film culture of the 1960s', Visual Anthropology Review, vol. 17, no. 2, p. 81.

2 See Spannaus, G. 1961, 'Der Wiessenschaftliche Film als Forschungsmittel in der Völkerkunde', Der Fil im Dienste der Wissenschaft, Institut für den Wissenschaftlichen, Göttingen, pp. 67-82; and de Brigard, E. 1995, 'The history of ethnographic film', in P. Hockings (ed.), Principles of Visual Anthropology, Mouton de Gruyter, Berlin and New York, pp. 13-43.
} 
I was also able to experience films of a very different genre: John Marshall's The Hunters and Robert Gardner's Dead Birds. ${ }^{3}$ These films were gripping in their narrative structure and in the raw emotions they conveyed. Belonging to a genre of films influenced by Flaherty's pioneering feature Nanook of the North (1922), they sat on the borders between documentary and narrative cinema, opening up ethnography to a wider audience. ${ }^{4}$

Peter Ucko had close links to the Royal Anthropological Institute (RAI). In British anthropology the RAI has always had a dialogical relationship with the academy. The RAI has carried the history of anthropology forward by keeping alive interests that the university academics have left behind. Arguably the RAI maintained the interdisciplinarity of anthropology at times when social anthropologists, archaeologists and biological anthropologists felt they had little in common. Yet the RAI was also sensitive to emerging issues arising from the grassroots of popular interest in areas ranging from child abuse, race relations and human rights to the teaching of anthropology in schools. The RAI maintained close links to museums and libraries and built significant archives of its own. It is not surprising, given its role in British anthropology, that in the 1970s it created two specialist research panels, one in art and the other in ethnographic film. The leading protagonists included Peter Ucko, Anthony Forge and James Woodburn. The two panels held regular meetings in London and, to an undergraduate student, they provided privileged access to two of the strands of the emerging discipline of visual anthropology. Sometimes they sat jointly as when Adriaan Gerbrands came to show his film Matjemosh. ${ }^{5}$

I saw two films in the early 1970s that had a great impact on me: David and Judith MacDougall's To Live with Herds, on the pastoral Jie of Kenya, ${ }^{6}$ and Ian Dunlop's Towards Baruya Manhood. ${ }^{7}$ The MacDougalls' film was of almost transcendent beauty, attuned to the aesthetics of the Jie. More than that it allowed the viewer to see the world from the perspective of the Jie as it emerged in dialogue with the filmmaker - how they coped with the difficulties of life facing drought. The commentary was a discourse internal to the film, the product of what David MacDougall later referred to as participatory cinema. ${ }^{8}$ Grimshaw has recently summarised the MacDougalls' achievement: 'By working with rather than

3 Marshall, J. 1957, The Hunters, Documentary Educational Resources, Watertown, Mass.; and Gardner, R. 1964, Dead Birds, A film produced by the Film Study Centre, Peabody Museum, Harvard University, Documentary Educational Resources, Watertown, Mass.

4 Heider, K. 2001-02, 'Robert Gardner: the early years', Visual Anthropology Review, vol. 17, no. 2, p. 66.

5 Gerbrands, A. 1964, Matjemosh, Stichting Film en Wetenschap, Utrecht. Karl Heider ('Robert Gardner') refers to it as 'an excellent film of its type - call the genre "Films Made By Anthropologists on The Side"'.

6 MacDougall, D. 1972, To Live with Herds, University of California at Los Angeles/Rice University Media Centre, Calif.

7 Dunlop, I. 1972, Towards Baruya Manhood, Film Australia, Lindfield, NSW.

8 MacDougall, D. 1995 [1975], 'Beyond observational cinema', in P. Hockings (ed.), Principles of Visual Anthropology, Mouton de Gruyter, Berlin and New York, pp. 115-32. 
against the distinctive aesthetic qualities of the medium, To Live with Herds began to outline the contours of a new anthropology. ${ }^{9}$ In Dunlop's case, I was present at the film's initial screening at the National Film Theatre in London, an event facilitated by James Woodburn. ${ }^{10}$ Towards Baruya Manhood is an account of the initiation ceremonies of the Baruya, a people of the Eastern Highlands of Papua New Guinea. It was made in collaboration with the anthropologist Maurice Godelier. It is a film of epic proportions, divided into nine sections, which together last for some eight hours. The film provides such detailed coverage that it enables the viewer to gain a sense of participation in the ritual, revealing the potential of film as a documentary process. My abiding image of the film is of the building of the ceremonial house as young men swing on tall poles bringing them together to be joined at the centre to create the framework of the building.

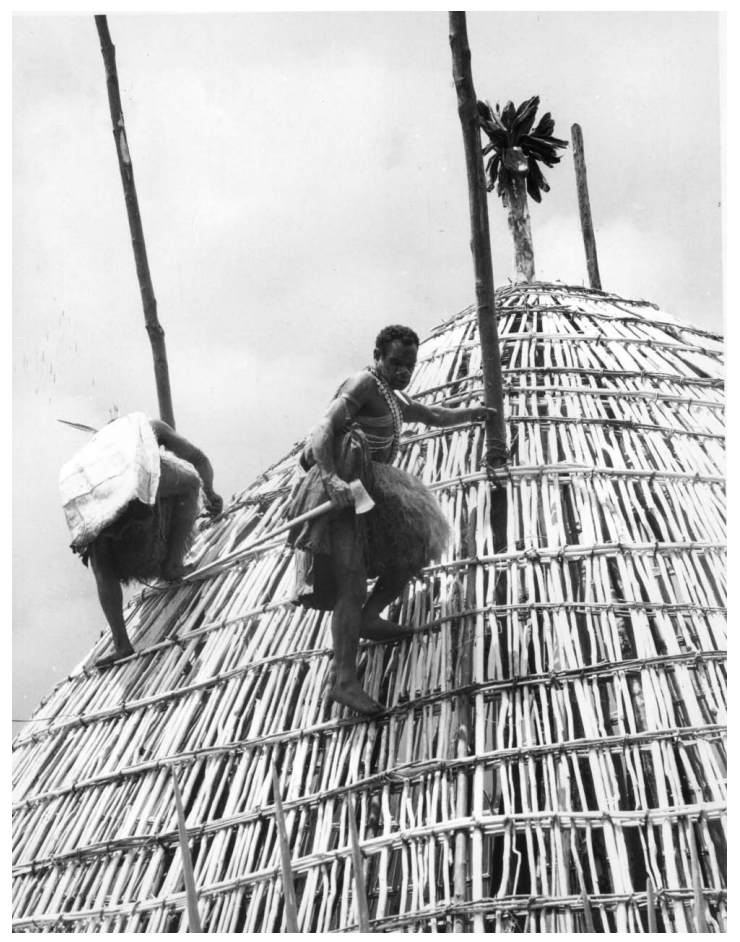

\section{Figure 1 The building of the chimya ceremonial house}

Source: Production still from Towards Baruya Manhood, 1969 (C NFSA, Film Australia Collection)

9 Grimshaw, A. 2011, 'The bellwether ewe: recent developments in ethnographic filmmaking and the aesthetics of anthropological inquiry', Cultural Anthropology, vol. 26, no. 2, p. 256.

10 For technical reasons, prints of the film required processing through a specialist laboratory in London since Kodak had not developed an inter-negative for the film stock used to shoot it. Dunlop had been spending part of the year attached to the National Film School at Beaconsfield at the invitation of Colin Young, who had been the MacDougalls' teacher at the Ethnographic Film Program at the University of California at Los Angeles. 


\section{Moving to the Epicentre}

In 1973 I arrived at The Australian National University to undertake doctoral research. I had no idea that in moving to Australia, and to Canberra in particular, I was moving to one of the epicentres, albeit fragile, of anthropological filmmaking. Anthropological filmmaking can arguably trace its origins to Haddon's 1898 Torres Strait Island expedition and Spencer and Gillen's pioneering work in central Australia in 1901. ${ }^{11}$ The subsequent years were fallow ones and indeed with few exceptions film was largely neglected by anthropologists until after World War II; however, that situation was beginning to change and in May 1973 the Museum of Modern Art in New York organised the first Major Retrospective on Anthropological Cinema. Australian films were well represented. The program included Spencer and Gillen's films and Ian Dunlop's Desert People ${ }^{12}$ and concluded with Towards Buruya Manhood. Roger Sandall's Gunabibi: An Aboriginal fertility cult, ${ }^{13}$ made with the assistance of anthropologist Nicolas Peterson, had a considerable impact on the program's guest director, Emilie de Brigard, and, in the program notes, she is quoted as feeling that the ceremony 'has the blood and grandeur of Wagnerian opera-Australian Aboriginal rites may seem offensive to some Westerners - there's nudity and painting of the body with blood - but to me because of films such as these Aborigines are among the most beautiful of people'. The program also included the MacDougalls' To Live with Herds.

In Canberra Frances Morphy and I prepared to undertake fieldwork in eastern Arnhem Land among Yolngu people. The focus of my research was to be on change in Yolngu art and in particular on bark paintings as market commodities. Two of Roger Sandall's films made with the assistance of Nicolas Peterson were part of my preparation for the field: Gunabibi and The Djungguwan of Yirrkala. ${ }^{14}$ The latter film was made at Yirrkala, which was to become the site of our own fieldwork. Sandall's films had been sponsored by the Australian Institute of Aboriginal Studies, which was paying for our fieldwork. When we arrived in Canberra, Sandall had already left to become a lecturer in anthropology at the University of Sydney. Nicolas Peterson, however, had a research fellowship in the Anthropology Department of the Research School of Pacific Studies, and we were able to meet him briefly before we left for the field.

\footnotetext{
11 See Rouch, J. 1970, 'Avant propos', in J. Rouch (ed.), Premier catalogue sélectif de films ethnographique sur la région du Pacifique, UNESCO, Paris, pp. 13-14; and Cantrill, A. and Cantrill, C. 1982, 'The 1901 cinematography of Walter Baldwin Spencer', Cantrill's Film Notes, nos 37-8 (April).

12 Dunlop, I. 1965, Desert People, Australian Commonwealth Film Unit, Lindfield, NSW.

13 Sandall, R. 1968, Gunabibi: An Aboriginal fertility cult.

14 ibid.; and Sandall, R. 1966, Djunguuan at Yirrkala, Australian Institute of Aboriginal Studies, Canberra.
} 


\section{Encountering Dunlop}

We arrived in Yirrkala at the beginning of July 1974. For Yolngu it was a time of uncertainty. They had lost a major court case to gain title to their land and were witness to a mining town being built on their doorstep. At the same time the Methodist Church was supporting moves towards increasing autonomy and selfgovernment for Yolngu and there were signs that their land rights were about to be recognised as a result of the Woodward Commission. Partly as a consequence of the advent of the mining town and the determination of people to protect their rights in land, the outstation movement had gained momentum. After a period of centralisation at the mission, people were moving out to establish small settlements on their traditional lands, with the support of the mission. In keeping with the desire for autonomy, people from outside were barred from visiting the outstations. It was a difficult time for two apprentice anthropologists to arrive in the field, and throughout our first weeks we struggled to overcome both our sense of being intruders and people's uncertainty about our role. Even in the case of a society as outgoing and accommodating of others as Yolngu have proved to be, there are times when people have to question the basis of their engagement with outsiders.

Before leaving for the field I had photographed the main collections of bark paintings from eastern Arnhem Land in museum collections. ${ }^{15}$ Part of my field methodology was to re-document the paintings and to establish the trajectory of Yolngu art over time. Each day I would try to find someone interested in going through my laminated sheets of photographs. On 9 July I visited Narritjin Maymuru with whom I hoped to work:

His approach was somewhat cool and it took a little while sitting before he gradually became warmer. He said that on the mission with people living together some of the stories some of the law had got confused and that on the outstations they had to agree on the one straight line on the songs and on the ceremonies. He was interested in the old paintings but showed me a folder of his own 'which is what we do now' - he is keeping the photographs so that if he dies before passing everything on to his sons, they will be able to copy it and the law won't be lost. It was a folder of photographs taken by Ian Dunlop. ${ }^{16}$

Narritjin let me know that he was expecting Ian Dunlop's arrival to film his return to his homeland, Djarrakpi. I was a little disappointed to hear that he was about to set off to Djarrakpi to prepare for Ian's arrival.

15 Morphy, H. 1991, Ancestral Connections: Art and an aboriginal system of knowledge, University of Chicago Press, Chicago.

16 Morphy, H. 1974, Fieldwork journal, 9 July. 
A month or so later Ian Dunlop arrived with his film crew and moved into the mission guesthouse, which we had made our home. It was an interesting time. Ian had been filming at Yirrkala since 1970 in what became known as the Yirrkala Film Project. The project was instigated to document the impact of the development of the bauxite mine and the mining town of Nhulunbuy on the people of Yirrkala. As Deveson shows, the project changed its focus over time and broadened partly because of the agency of the Yolngu people. ${ }^{17}$ In addition to documenting the mine and people's response to it, Dunlop agreed to Yolngu requests to film their life more generally, in particular their ceremonial performances.

Ian's memories of Frances and me in the early days of his meeting us are hardly flattering. He recalls that we left each day in the heat of the morning sun burdened by heavy Uher tape recorders, bags and cameras, to return several hours later sweaty, exhausted and frustrated, having found all the people we intended to talk to about our research were away somewhere else. Certainly the initial months of fieldwork as an anthropologist are not easy ones! Over the next two years we spent much of the time living at Yirrkala and developed a close working relationship with Ian that has continued to the present.

All ethnographic filmmakers develop their own style in dialogue with developments in anthropology as well as in film and cinema. ${ }^{18}$ Few in number, they have often taken a leading role in both disciplines. The late 1960s saw the beginnings of a time of paradigmatic change in anthropology, though perhaps not one that created discontinuities with the discipline's past as major as some have argued. Anthropology became increasingly the centre of contested theoretical frameworks. ${ }^{19}$ Anthropologists were becoming more aware of the ethical dimension of their work in an increasingly postcolonial world. ${ }^{20}$ This resulted in an increasing focus on the nature of representational processes and their relationship to power and authority. A reflexive theme developed in anthropology and emerged strongly in the 1980s. ${ }^{21}$ Visual anthropologists from the 1960s on were fully engaged in this process of change, in particular in foregrounding the dialogical nature of anthropological research, giving agency to the participants and in exploring new ways of communicating anthropological knowledge by using the potential of visual media. Anna Grimshaw summarises what she refers to as the observational turn in ethnographic filmmaking well when she writes that it 'signaled a significant epistemological, philosophical,

17 Deveson, P. 2011, 'The agency of the subject: Yolngu involvement in the Yirrkala Film Project', Journal of Australian Studies, vol. 35, no. 2, pp. 153-64.

18 MacDougall, 'Colin Young, ethnographic film and the film culture of the 1960s', p. 82.

19 Leach, E. 1961, Rethinking Anthropology, Athlone Press, London.

20 Asad, T. (ed.) 1973, Anthropology and the Colonial Encounter, Ithaca Press, London.

21 Clifford, J. and Marcus, G. 1986, Writing Culture: The poetics and politics of ethnography, University of California Press, Berkeley. 
and aesthetic shift. It was founded in a new approach to the world that respected its materiality, its continuity, and fundamental ambiguity. And it hinged on a different conception of knowledge, one that was fundamentally relational.' ${ }^{22}$

In Ian Dunlop's case his films moved from an almost romantic genre, in the case of Desert People, sharing a family relationship with Flaherty's Nanook of the North, to a mode of anthropological filmmaking that gave voice and agency to the people being filmed. By the time of the Yirrkala Film Project, Dunlop was determined to use advances in synchronous sound recording and subtitling to convey Yolngu views about the impact of the mine in conversations amongst themselves and with him as an interviewer. Dunlop had also become part of the world discourse in ethnographic film through his participation in the United Nations Educational, Scientific and Cultural Organisation (UNESCO) Round Table in Ethnographic Filmmaking in the Pacific, held in Sydney in $1966 .{ }^{23}$ Ian was, however, far from being a free agent himself. The nature of his filmmaking was influenced by the fact that he worked within the relatively conventional framework of the Commonwealth Film Unit and as a member of a team, which included himself as director with a soundperson and cameraman. This imposed certain constraints in financial terms and on the time he was able to spend in the field. Ian was also in a sense working for a number of different 'masters': the Commonwealth Film Unit, the Australian Institute of Aboriginal Studies (AIAS), who provided additional funding, and Yolngu people themselves. The first required films that fitted the original brief of documenting the impact of the mining town, the AIAS encouraged the documentation of aspects of Yolngu 'traditional' culture, and Yolngu took Dunlop at his word that he was working in partnership with them. In the end the diversity of films produced became the positive outcome of the contradictory pressures that he experienced, and reflect his persistence in working to produce the kind of film he believed to be appropriate for the topic. The films overall range from investigative documentary through biography to recordings of ceremonial performance. ${ }^{24}$

Our chance encounter with Ian, combined with his essentially collaborative nature, was to result in our lifelong engagement with ethnographic film and provided us with access to resources that would greatly facilitate our own research. Over the following two years in the field we began to work closely with Ian on a number of film projects, with Frances and I becoming de facto anthropological consultants in the field. Nancy Williams, who had been the official consultant on the initial project, also continued as an advisor and an invaluable supporter to our own research.

22 Grimshaw, 'The bellwether ewe', p. 255.

23 See Deveson, this volume.

24 Morphy, H. 2006, 'The aesthetics of communication and the communication of cultural aesthetics - a perspective on Ian Dunlop's films of Aboriginal Australia', Visual Anthropology Review, vol. 21, nos 1-2, pp. 63-97. 
Our roles in working with Ian and his film grew over time. I developed a close relationship with many of the people whom Ian had been filming, in particular the artists Narritjin Maymuru and Dundiwuy Wanambi. Frances began working on her grammar of the Djapu language and I began to understand more about the social context of Yolngu art and ritual. In addition to providing some relevant information, I became a useful production assistant, helping with lighting night-time shooting by holding the sun gun, carrying reels of film, collecting water from the spring and generally learning the business.

Ian had no intention of filming ritual when he first arrived at Yirrkala. He understood that his main focus should be on the impact of the mine. Yolngu had other ideas. They were aware that previous filmmakers had made recordings of Yolngu ceremonial performances. Filmmakers were interested in filming ritual and Yolngu were interested in having films made of their rituals. Yolngu motivations were complex but the one most commonly expressed was to make a record for future generations so that they would be able to learn from it. Ian had filmed a number of rituals prior to us beginning fieldwork, including a circumcision ceremony, a house-opening and a major memorial ceremony based on the form of the Dhuwa moiety Ngärra. ${ }^{25}$

Dundiwuy Wanambi, a leader of the Marrakulu clan, planned to hold a Djungguwan ceremony at his homeland of Gurka'wuy on Trial Bay in the dry season of 1976. Dundiwuy had worked closely with Ian and had been a participant in the earlier performance of the same ceremony that had been filmed by Roger Sandall. He persuaded Ian to make a film of 'his' Djungguwan, and Frances and I were invited along as assistants. ${ }^{26}$ In the event two ceremonies were filmed; while preparations were under way for the Djungguwan, a young child died in the night and a burial ceremony was held for him.

In the weeks we spent at Gurka'wuy I became totally absorbed in the process of filmmaking and began to realise the potential that film had for anthropological research. Yolngu rituals are complex events and, as Emelie de Brigard perceptively noted, operatic in their scale. Yet to the casual observer they are scripted anew each time they are performed. Each burial ceremony, and each circumcision ceremony, seems to differ from the one before. In seeing a Yolngu ritual for

25 Dunlop, I. 1983, In Memory of Mawalan, Film Australia, Sydney.

26 The result was Dunlop's 1989 film monograph, Djungguwan at Gurka'wuy (Film Australia, Sydney). The film lasts for some five hours and the title signals Dunlop's intention to produce a documentary film that provides an anthropological interpretation of the event in addition to giving the opportunity to observe the performance. A follow-up almost two decades later was the production of a DVD, Ceremony - The Djungguwan of Northeast Arnhem Land (Graham, T. 2006, Film Australia, Sydney). The DVD resulted from filmmaker Trevor Graham being persuaded by Yolngu to film another Djungguwan ceremony at Yirrkala in 2002. In addition to Graham's film, the DVD includes an edited version of Dunlop's film as well as edited sequences from Sandall's 1966 film. The three films provide a perspective on the ways in which the Djungguwan ceremony has changed over nearly forty years. The DVD also includes complementary filmed commentaries by the filmmakers and anthropologists involved in the two projects. 
the first time everything surprises. It is like being present at the opening performance of a play in a foreign language one barely speaks. Filming a Yolngu ritual requires recording on film events that one does not fully understand at the time, without a script to let you know what is coming next.

After observing a number of mortuary rituals, I began to be attuned to the possibilities and sense the structure. There are sequences of events that usually occur in a given order, though the content of those events, the particular singing and dancing sequences performed, their number and variation will differ every time. ${ }^{27}$ The child's funeral at Gurka' wuy was the third one I had attended and the Djungguwan the second. But I must confess that the previous ceremonies were only partially recorded. I was not at Yirrkala to record ritual but to work on the iconography of paintings and, although I saw the relevance of the ritual context to understanding Yolngu art, my primary focus was on the art objects themselves. Attending ceremonies for days on end was a diversion. I dropped in on ceremonies and attended the high points. Ian Dunlop's objective was to provide as comprehensive a record of the events as possible and in assisting him I had to pay attention of a different kind. I had to follow the camera into the heart of the action but always be aware of the wider context, if only to make sure that I kept out of the shot. Ian was certainly not concerned to erase my presence but neither did I want to interrupt the viewer's engagement with the ritual action. And I had to document the event as meticulously as I could in order to assist with the editing.

On the occasions I worked with Ian he was part of an exceptional team, with Dean Semler as his cameraman. Ian's method as director was to remain for the duration of a shot as close to the eye of the camera as he could be without looking through the lens - almost an adjunct to the cameraman, able to whisper in his ear and alert him to action happening elsewhere. Though there would of course be many occasions where there was room for the cameraman alone. In Semler's case, little prompting was necessary, as he seemed to know instinctively when to widen the shot and when to close in, how to film a complex and apparently chaotic moment of ritual action so that when it was viewed the order was revealed. Indeed when reviewing the filmed material in the cutting room it was surprising how much it made sense and how little appeared to be missing. How Ian and Dean were able to achieve this in itself provides insights into the nature of Yolngu ritual action, its organisational structure and to the relative autonomy of the aesthetic flow of the event.

Yolngu rituals build up sequences of action through processes of repetition and recursion. The performers will repeat the same song and sequence of action a number of times before moving onto the next, and an analogous episode may

27 Morphy, H. 1984, Journey to the Crocodile's Nest, Australian Institute of Aboriginal Studies, Canberra. 
be enacted a number of times by a different group of people. For example, a series of different dances may be performed as a prelude to opening a shade where a body lies waiting for burial; each dance concludes with the symbolic opening of the shade. ${ }^{28}$ As sequences are repeated, the intensity builds until a concluding act is performed or the climax signalled, after which people move on to the next episode. At times one song flows into the next and often it is difficult to determine when a song has ended or when one is about to begin. This posed difficulties to a filmmaker in the pre-digital era when there was a need to conserve film. One of the things that Ian learnt early on in his filmmaking with Yolngu was that it was important to them to capture the beginning of the song and to record it as a whole. This also fitted in with Ian's own desire to create a sense of time associated with the ritual performance rather than aim to produce edited highlights of the most dramatic action.

What Ian learnt about filming Yolngu ritual made his film an exceptional resource for anthropological research and for re-documenting because the contextual material was there. The moments before and after a particular song had been sung, in which people discuss where to go next or make specific references to peoples' connections to the song, were all there to be discovered in the process of translation. The very fact of reviewing the material with different participants also yielded a diversity of perspectives, all of which were relevant to understanding the significance of the ritual action. ${ }^{29}$ Yet at the same time the filming of particular dramatic episodes and the powerful flow of action contained within them enabled one to be attuned to the aesthetic of the performance as a whole and how it might create an inter-subjective sense of being part of a whole.

\section{Connecting to Canberra}

While we were becoming involved in ethnographic filmmaking in the field with Ian Dunlop, serendipity was at work in Canberra. In 1975 we returned there for a mid-fieldwork break and began to analyse our material. We learnt that David and Judith MacDougall had arrived at the Australian Institute of Aboriginal Studies to run the film unit. When we returned from our second period of fieldwork in 1976, Timothy Asch had arrived as a Research Fellow in the Anthropology Department at the Research School of Pacific Studies. Tim was accompanied by his wife, Patsy Asch, with whom he collaborated on many of his film projects. 
Tim Asch had been at the heart of developments in ethnographic film in the United States. He was a passionate advocate of the use of film in teaching anthropology and as a means of communicating the results of anthropological research. He had been a graduate assistant to Margaret Meade, one of the pioneers of visual anthropology. He used new technology and in particular developments in subtitling to create films that analysed particular events captured on camera. His most renowned film is probably The Ax Fight (1975), one of the series of films he produced on the Yąnomamö as a result of his collaboration with the anthropologist Napoleon Chagnon. ${ }^{30}$ The use of freeze-frame and enlargements enabled him to enter into the course of a fight that began on the far side of the village compound and was caught in a distant shot. The Ax Fight was an educational film but at the same time a real-life documentary drama brought to life by the techniques of cinema. Asch had worked closely with John Marshall and with him established Documentary Educational Resources, one of the main resources for the archiving and distribution of ethnographic film.

The Aschs and the MacDougalls encouraged people who were interested to become involved in their filmmaking. Tim and Patsy worked closely with a number of ANU anthropologists in the field. James Fox was appointed an Associate Professor of anthropology at The Australian National University in 1975. He had worked with Tim Asch previously at Harvard and was instrumental in his appointment to The Australian National University. The Aschs worked closely with James Fox and with a number of doctoral students undertaking fieldwork in Indonesia, in particular Douglas Lewis and Linda Connor. ${ }^{31}$ The MacDougalls' method of filmmaking was different; essentially they were their own ethnographers. But they involved colleagues in viewing and providing feedback during the editing process; however, as far as I was concerned, perhaps the most important contribution the MacDougalls and the Aschs made was to establish an informal forum for colleagues and graduate students who were passionate about ethnographic and documentary film in the Friday-evening film screenings that rotated from house to house. The meetings were open to all who were interested but revolved around a core of regular participants including Anthony Forge, Ros and Nic Peterson, Andrew and Merrilyn Pike, John and Lesley Haviland, Roger and Shelley Keesing, the Morphys, Douglas Lewis, and assorted young children. Most of the participants had themselves some direct or indirect involvement in ethnographic film. Anthony Forge was an excellent photographer; he had shot his own footage in the field and had worked with a number of filmmakers. Nicolas Peterson had made one film himself in the field (Nomads in Clover, 1966) in addition to working closely with Roger Sandall.

30 Asch, T. 1975, The Ax Fight, Documentary Educational Resources, Watertown, Mass.

31 See Lewis, D. 2004, Timothy Asch and Ethnographic Film, Routledge, New York; and Connor, L., Asch, P. and Asch, T. 1986, Jero Tapakan: Balinese healer-An ethnographic film monograph, Cambridge University Press, Cambridge. 
Keesing and the Havilands had strong interest in the use of film in linguistics and anthropology and Andrew Pike was both a historian of film and a filmmaker. Complementing the quality of the films was the quality of the food and wine that accompanied our fellowship.

Canberra at that moment in time was probably the best place in the world to be for a graduate student with a developing interest in ethnographic film. In addition to being provided with a privileged environment for learning about the history of documentary film, appreciating how films were made and how they created meaning and experience, I was placed in an environment that gave me the confidence to give a central role to film in my anthropological apprenticeship.

My involvement with Ian Dunlop in the middle of research for my doctorate required a commitment that proved time-consuming. In addition to spending longer in the field than I otherwise would have done, on my return from the field Ian gave Frances and me the opportunity to document the footage in Film Australia's studios in Sydney. Ian's method of filmmaking involved an initial documentation process in which he went through the material with Yolngu participants and then re-documented it again where possible with his anthropological consultants. This meant that in addition to providing assistance to Ian we were both able to review the material again and again, and have access to supplementary ethnographic data from different participants. I found this a very exciting opportunity and had little doubt that it would enable me to write a much better, if somewhat delayed, thesis. My supervisor, Anthony Forge, although he remained very supportive, was less certain. During the filming of the Djungguwan ceremony, which took place towards the end of my second field trip, I received occasional messages ordering me to return from the field, which I was able to quietly ignore. And back in Canberra our trips to Sydney caused raised eyebrows; however, the fact that Anthony was so strongly engaged with the ethnographic film scene in Canberra gave me the confidence not to be too concerned about his occasional voiced disapproval of the priorities I set myself.

The slight tension over priorities continued after my thesis on Yolngu art was completed. I was fortunate enough to get a short-term teaching position at The Australian National University, which eventually became permanent. One of the films that Ian had completed first was the film made of the child's funeral that intervened in the preparation for the Djungguwan ceremony. I had documented the ceremony in great detail at the time, it was relatively self-contained and I sensed that I had developed a real understanding of it as an event. Ian's film Madarrpa Funeral at Gurka'wuy captured the sense of the ritual as a whole as well as its emotional intensity. ${ }^{32}$ 
Yolngu mortuary rituals provide a context in which, in as much as it is possible, the 'society' reveals its structure to itself. In his field notes of 29 July 1937, Donald Thomson wrote, 'if a man could but follow all that takes place when a yarkomirri [yäkumirri"important"; lit. "name-having"] man dies he would understand almost all of the culture of these people'. ${ }^{33}$ Thomson exaggerates somewhat and in the case of the Madarrpa funeral it was the burial of an infant an event of much less significance. Nonetheless, I felt that the film could be used to illustrate fundamental features of Yolngu society and ritual. The film was divided into two forty-five-minute segments and recorded a public event that Yolngu were happy to see screened to open audiences. Ian saw its potential use in teaching and I had the idea of writing an accompanying monograph. Again, Anthony Forge was not sure that I had my priorities right. He did not think that a book of the film would enhance my career and felt that I should begin immediately to convert my thesis on Yolngu art into a book; however, the atmosphere of those Friday-evening film screenings won out. Tim Asch was a strong advocate for producing monographs to accompany ethnographic films and strongly supported me in my endeavour. The result was the publication of my first book, Journey to the Crocodile's Nest: An accompanying monograph to the film Madarrpa Funeral at Gurka'wuy. ${ }^{34}$

\section{Ethnographic Film and Anthropology}

In the 1970s I found myself on the edge of a network of practitioners who were creating ethnographic film in its contemporary form. There had been an earlier history of significant advocates for the use of film in anthropological research, in particular Margaret Mead and Gregory Bateson. But by the 1960s there were signs that a discipline or body of practice was emerging: in France with Rouch; in the United States with Marshall, Gardner, Asch and the MacDougalls; and in Australia with Sandall and Dunlop. In addition, Colin Young appeared almost as a magician, acting as a catalyst in bringing people together and creating teaching programs for students that provided institutional entry points into a possible profession. Colin Young had become Dean of the Department of Theatre Arts at the University of California at Los Angeles (UCLA) in 1964 and subsequently became the foundation director of the British National Film School. According to MacDougall, who was one of his students at UCLA, Young's idea was to 'bring anthropology and film students together for a year and expose them to one another's disciplines' and to teach people new skills they could take back to

33 Peterson, N. 1976, 'Mortuary customs of northeast Arnhem Land: an account compiled from Donald Thomson's fieldnotes', Memoirs of the National Museum of Victoria, vol. 37, pp. 97-108.

34 Published in 1984 by the Australian Institute of Aboriginal Studies, Canberra. 
their own disciplines. ${ }^{35}$ It was uncertain precisely what kind of relationship would develop between film and anthropology and controversies over whether one was subordinate to the other raged for a time. ${ }^{36}$ Film has the potential to contribute to most areas of anthropology. But perhaps - and here I am showing my own biases - a synergistic relationship developed between those interested in film and those interested in materiality and expressive culture: on the one hand in art, in performance, in the aesthetics of the environment, and on the other hand in ways of being. These synergies between ethnographic film and a focus on the material world enabled a discipline of visual anthropology to grow in such a way that the component interests within it tended towards mutual reinforcement. Visual anthropology had been the apprehension of Mead and Bateson and in subsequent years has become an increasingly important segment of the discipline. ${ }^{37}$

Ethnographic film since the 1960s has become a core part of the field of visual anthropology as well as being a genre of filmmaking in its own right. I would argue that the inclusion of film within this growing field can make it a more central part of the discipline of anthropology as a whole rather than reducing its potential to contribute in innovative ways. The opposition that is sometimes proposed between film as a methodological tool for anthropology and film as a medium of artistic expression is false. It fails to see different media as relatively autonomous bodies of knowledge, practice and expertise with the capacity to contribute in unique ways to theoretical understanding 'and be fully appreciated as modes of inquiry in their own right' ${ }^{38}$ Different media can convey ideas and understandings about people and events by utilising their own communicative potentials and expressive properties. Film's contribution to anthropology in the work of filmmakers such as Gardner, Rouch and the MacDougalls has been partly through their understanding of the potential of film independent of the particular disciplinary context. ${ }^{39}$

\section{Conclusion}

My entanglement with ethnographic film during my apprenticeship as an anthropologist had a profound and beneficial influence on my subsequent career.

35 MacDougall, 'Colin Young, ethnographic film and the film culture of the 1960s', pp. 83-4.

36 Ruby, J. 2000, Picturing Culture: Explorations of film and anthropology, University of Chicago Press, Chicago.

37 See Hockings, P. (ed.) 1975, Principles of Visual Anthropology, Mouton de Gruyter, Berlin and New York; Banks, M. and Morphy, H. 1997, Rethinking Visual Anthropology, Yale University Press, New Haven, Conn.; and Ruby, J. and Banks, M. 2011, Made to be Seen: Perspectives on visual anthropology, University of Chicago Press, Chicago.

38 Grimshaw, 'The bellwether ewe', p. 256.

39 See Henley, P. 2009, The Adventures of the Real: Jean Rouch and the craft of ethnographic film, University of 
My work with Ian Dunlop gave me access to an exceptional resource to study Yolngu ritual in depth. Engagement with the MacDougalls and the Aschs enabled me to understand the value of film in teaching and research in anthropology. I was able to learn much about filmmaking as a participant observer to the extent to which, in the absence of Ian Dunlop, I could be called upon by Yolngu to help to continue to add to the visual archive of their society. ${ }^{40}$ Film became relevant to many of the key debates in anthropology over the subsequent decades, on the nature of representation, on the authority of the anthropologist, on the agency of the Indigenous subjects, on the role of aesthetics and the senses in the social life and many other topics. My interest in film enabled me to enter many of these debates; however, perhaps more than anything else my involvement has enabled me to understand the frustrations of anthropological filmmakers with the failure of the discipline to recognise the potential of film in anthropological research in communicating ideas and a sense of being in the world across cultures.

Making ethnographic or anthropological films has been until recently a very expensive project in both time and money. It has existed in a domain of academic research and production that has only relatively recently been fully acknowledged - that of practice-led research. Ethnographic filmmakers have to develop an aptitude in the art of filmmaking as well as being able to participate in the intellectual discourse of anthropology. At the same time it has until recently been difficult to fit film into anthropological teaching practice. The logistics of incorporating film in teaching programs was not easy and required lecturers who would put considerable efforts into structuring classes around them, providing supplementary information and working through the material themselves. Producing and using film in anthropology required skill sets that most anthropologists did not possess. This is not surprising since it applies across most academic disciplines in which practice is dominated by writing and the production of texts. Film was also perhaps too closely associated with pleasure and entertainment - something that could occasionally be substituted for a lecture to ease the burden on the lecturer and provide relief for the students. It almost follows on from that that the production of film was devalued in academic terms and its practitioners were not given the credit for work that flowed to others through monographs and journal articles. And yet anthropological film has over time survived and grown and the digital revolution that has taken place in recent years has opened up unprecedented possibilities for its inclusion in research and teaching.

40 In 2003 I was asked to film the burial ceremony of a leading member of the Madarrpa clan. Yolngu knew that I had worked closely with Ian Dunlop and thought that I might be able to organise a film crew to come to Yilpara on Blue Mud Bay. Unfortunately it was impossible to organise anything in the time available so I volunteered to film the event myself. I have subsequently made a number of films working with Philippa Deveson as editor, including In Gentle Hands (Morphy, H. and Deveson, P. 2008, The Australian National University, Canberra). 
There is still a long way to go before anthropology fully recognises film as being the equal of text and is able to use its potential as both a medium of communication and a mode of inquiry. While new technology does not in itself result in conceptual change, developments in digital technology have created a revolution in communication that has in many respects advantaged the visual. Student interest in film has perhaps always been ahead of faculty. Today we are moving into an environment in which students' capacity to use digital media and see its potential is in advance of many of their teachers'. Film and photography are becoming media for everyday communication. The hope is that the body of knowledge and understanding that developed with the practice of ethnographic film when its potential was unseen by the discipline are brought into the present and integrated fully within contemporary anthropological discourse. 